\title{
Addition of a fungal protease to low and high protein sorghum- or wheat-soyabean meal diets on ileal amino acid digestibility and performance of growing pigs
}

\author{
M. Cervantes ${ }^{1}$, J. González ${ }^{1}$, N. Torrentera ${ }^{1}$, V. González', \\ M. Cervantes ${ }^{1}$ and M. Cuca ${ }^{2}$ \\ 'Instituto de Ciencias Agricolas, Universidad Autónoma de Baja California \\ Mexicali, Baja California, México \\ 'Colegio de Postyraduados \\ Montecillo, Edo. México, México
}

(Received 12 February 2001; accepted 7 August 2001)

\begin{abstract}
Three experiments were conducted to assess the effect of adding a fungal protease to low (LP) and high protein (HP) diets on the apparent ileal digestibility (AID) of amino acids (AA) and performance of growing pigs. In Experiment 1, eight pigs, fitted with two cannulas (proximal duodenum and distal ileum) were used. Twenty eight pigs were used in Experiments 2 and $3(27.5$ and $24.0 \mathrm{~kg}$ initial body weights, respectively). Dictary treatments ( $T$ ) for the three experiments were as follows: T1. LP diet; T2. LP plus $0.5 \mathrm{~g}$ protease $/ \mathrm{kg}$ feed (LP-P); T3. HP diet; T4. HP plus $0.5 \mathrm{~g}$ protease $/ \mathrm{kg}$ feed (HP-P). The diets included sorghum in Experiments 1 and 2, and wheat in Experiment 3. The AID of AA, except for leucine, were higher $(\mathrm{P}<0.01)$ in pigs fed the HP diets. The addition of protease to the LP diet increased $(P<0.01)$ the AID of $A A$, except for lysine. In contrast, addition of protease to the HP diet did not affect $(P>0.10)$ the AID of AA. Intestinal disappearance (ID) of AA was higher $(\mathrm{P}<0.01)$ in pigs fed the HP compared to the LP diets. Addition of protease to the LP diet increased $(P<0.05)$ the $1 D$ of $A A$, but was still lower than that of pigs fed the HP diets $(P>0.05)$. Pigs fed the HP sorghum diets had a higher daily gain, feed intake and a better feed/gain ratio $(\mathrm{P}<0.05)$ than pigs fed the LP diets; however, there was no effect $(P>0.05)$ of $\mathrm{CP}$ level in pigs fed the wheat diets. Addition of protease tended to depress performance of pigs fed the sorghum diets, but did not affect the performance of pigs fed the wheat diets. These results suggest that lysine and threonine intakes, rather than the amino acid digestibility are the factors that limit growth in pigs fed LP-amino acid fortified, sorghum-soyabean meal dicts. These data also show no beneficial effect of adding a protease to sorghum- or wheat-based diets on the AID of AA and the performance of growing pigs.
\end{abstract}

KEY WORDS: pigs, amino acid, apparent digestibility, protease, performance 


\section{INTRODUCTION}

The supplementation of free amino acids (AA) to low crude protein (CP) diets improves the AA balance of the diet (Russell et al., 1983) and, as a consequence, reduces the environmental damage by decreasing the nitrogen excretion through the faeces and urine (Cromwell, 1996). Moderate reduction of the CP level (up to four percentage units) of sorghum-based diets, coupled with supplementation of lysine and threonine, does not affect pig performance (Cervantes et al,, 1997). However, further reduction of the dietary CP level (more than four percentage units) reduced the growth rate and feed efficiency of pigs, even though these diets were supplemented with all the limiting nutrients (Hansen et al., 1993). In contrast, growing pigs fed wheat-based diets without soyabean meal, but supplemented with crystalline lysine and threonine, performed as well as those fed a $17 \% \mathrm{CP}$ wheat-soyabean meal diet.

Recent reports show that the dietary CP level may affect the apparent ileal digestibility (AID) of AA in pigs (Fan et al., 1994; Cervantes et al., 1997). The proportion of endogenous protein to indigested exogenous protein may contribute to this difference. However, Corring and Saucier (1972) found an increase in total chymotrypsin activity in growing pigs as the protein content of maize starch-based diets was raised from 0 to $40 \%$, suggesting that high protein are more digested than low protein sorghum-based diets. The aforementioned reports suggest that the poor performance of pigs fed low protein, AA-fortified, sorghum-based diets may be partially due to a reduction in AA digestibility values. Thus, the addition of a protease to the diet may increase AA digestibility; which in turn, would improve the performance of growing pigs fed low protein-AA fortified diets. There is a scarcity of information regarding the effect of exogenous proteases on the AA digestibility values in pigs fed low protein diets. Therefore, three experiments were conducted to determine if the addition of a fungal protease, to sorghum- or wheatbased diets containing low or high CP levels, improved the AID of AA, intestinal disappearance (ID) of AA, and performance of growing pigs.

\section{MATERIAL AND METHODS}

\section{General procedure}

Three experiments were conducted at the Swine Experimental Unit of the Universidad Autónoma de Baja California to evaluate the effect of adding to sorghumor wheat-based diets a fungal protease produced by Aspergillus niger, on the AID values of AA and performance of growing pigs. The activity of the enzyme was equivalent to 180,000 haemoglobin units $(\mathrm{HU}) / \mathrm{kg}$ of feed, at $\mathrm{pH} 4.7$. All pigs were 
individually housed in pens with a raised, plastisol coated mesh floor. Water was freely available at all the times.

Experiment 1. Eight crossbred (Landrace $\mathrm{x}$ Hampshire $\mathrm{x}$ Duroc) gilts (average BW $25 \mathrm{~kg}$ ), each fitted with two "T-type" cannulas, one in proximal duodenum (approximately $15 \mathrm{~cm}$ caudal to the pancreatic duct), and the other at the distal ileum (approximately $10 \mathrm{~cm}$ from ileo-caecal valve) were used. Duodenal cannulation was used to determining activity of pancreatic enzymes, but the results are not presented in this report. Surgical placement of the cannulas, as well as pre- and post-operative care, was previously described by Cervantes et al. (2000). Immediately after surgery, the gilts were placed individually in metabolism cages. All pigs completely recovered within 10 to $12 \mathrm{~d}$ after surgery, as indicated by the absence of inflammation around the fistula and normal feed intake (similar to that before surgery). Feed was provided $24 \mathrm{~h}$ post-surgery. During the recovery period, all pigs received a $16 \% \mathrm{CP}$ sorghum-soyabean meal diet. Following recovery, the gilts were fed one of four experimental diets (Table 1).

The study was conducted as a two-period, crossover design. Each experimental period consisted of $15 \mathrm{~d}, 10 \mathrm{~d}$ of diet adaptation and $2 \mathrm{~d}$ for collection of ileal digesta. Pigs were fed two times daily $(07.00$ and $19.00 \mathrm{~h})$, equal amounts each meal. Feed intake was limited to 3.5 times the DE maintenance requirement (NRC, 1988) of the gilts based on their BW at the beginning of each experimental period. Feed was provided as liquid form, at a water:feed (2:1) ratio. The enzyme was

TABLE 1

Composition of basal experimental diets (as fed basis), $\mathrm{g} / \mathrm{kg}$

\begin{tabular}{|c|c|c|c|c|}
\hline \multirow{2}{*}{ Ingredient } & \multicolumn{2}{|c|}{ Experiments 1 and 2} & \multicolumn{2}{|c|}{ Experiment 3} \\
\hline & low protein & high protcin & low protein & high protein \\
\hline Sorghum & 915.9 & 804 & - & - \\
\hline Wheat & - & + & 964 & 819.1 \\
\hline Soyabean meal $(48 \%)$ & 45.3 & 162.2 & - & 151.9 \\
\hline L-lysine $\cdot \mathrm{HCl}$ & 3 & - & 5.5 & - \\
\hline L-threonine & 1.5 & - & 1.5 & - \\
\hline DL-methionine & 0.5 & - & - & - \\
\hline Calcium carbonate & 8.7 & 8.7 & 11.8 & 11.8 \\
\hline Dicalcium phosphate & 12.6 & 12.6 & 8.7 & 8.7 \\
\hline Iodized salt & 3.5 & 3.5 & 3.5 & 3.5 \\
\hline Vitamin and trace mineral premix & 4.0 & 4.0 & 4.0 & 4.0 \\
\hline Antibiotic $^{2}$ & 1.0 & 1.0 & 1.0 & 1.0 \\
\hline Chromic oxide & 4.0 & 4.0 & - & - \\
\hline
\end{tabular}

' supplied per kg of diet: vit. A, $4800 \mathrm{IU}$; vit. $\mathrm{D}_{3}$, $800 \mathrm{IU}$; vit. E, $4.8 \mathrm{IU}$; vit. $\mathrm{K}_{3}, 1.6 \mathrm{mg}$; riboflavin, $4 \mathrm{mg} ; d$-pantothenic acid, $7.2 \mathrm{mg}$; niacin, $16 \mathrm{mg} ;$ vit. $\mathrm{B}_{\mathrm{l} 2}, 12.8 \mu \mathrm{g} ; \mathrm{Zn}, 64 \mathrm{mg} ; \mathrm{Fe}, 64 \mathrm{mg} ; \mathrm{Cu}, 4 \mathrm{mg}$; $\mathrm{Mn}, 4 \mathrm{mg} ; \mathrm{I}, 0.36 \mathrm{mg} ;$ Se, $0.13 \mathrm{mg}$

2 supplied $200 \mathrm{mg}$ Oxytetracycline $\cdot \mathrm{HCl}$ per $\mathrm{kg}$ of diet 
added and mixed with the feed at the same time water was added. Pigs were trained to consume their ration in $15 \mathrm{~min}$ or less. Ileal digesta were collected in plastic bags tied to the barrel of the cannula. The bags were removed and replaced as soon as it was filled with digesta; no bag remained attached to the cannula longer than $30 \mathrm{~min}$. Digesta were collected on $\mathrm{d} 11$ and 12 , alternating $6 \mathrm{~h}$ of collection with $6 \mathrm{~h}$ without collection; it started on $\mathrm{d} 11$ from 06.00 to 12.00 , and completed on d 12 from 00.00 to 06.00 .

Experiments 2 and 3. Twenty eight crossbred (Landrace $\mathrm{x}$ Hampshire $\mathrm{x}$ Duroc) pigs (27.5 and $24.0 \mathrm{~kg}$ average initial BW in Experiments 2 and 3, respectively) were used in each experiment to determine the performance of growing pigs. In each experiment, pigs were randomly allotted to the four dietary treatments (Table 1), on the basis of sex, age, BW and litter, according to a randomized complete block design, with a $2 \times 2$ factorial arrangement. In both experiments there were seven replicates per treatment. Pigs were weighed cach week; feed intake, and gain:feed ratio were measured also every week. Each experiment lasted four weeks.

\section{Experimental diets}

The experimental diets consisted of sorghum- (Experiments 1 and 2) or wheat(Experiment 3) soyabean meal diets, fortified with minerals and vitamins (Table 1). The treatments for the three experiments were as follows: T1. low protein diet (LP); T2. LP plus $0.5 \mathrm{~g}$ protease $/ \mathrm{kg}$ feed, equivalent to 90 hacmoglobin units (HU) (LP-P); T3. high protein diet (HP), and T4. HP plus $0.5 \mathrm{~g}$ protease $\mathrm{kg}$ feed equivalent to $90 \mathrm{HU}$ (HP-P). The HP diets were formulated to provide at least $110 \%$ the requirements of the essential $\mathrm{AA}$ for pigs ranging in $\mathrm{BW}$ from 20 to $50 \mathrm{~kg}$ (NRC, 1988). In all experiments, crystalline lysine and threonine were included in the LP diets to meet the requirements for growing pigs. These AA were added to the LP diets used in the digestion trial to avoid differences in the growth rate of pigs and to keep the feed intake constant across treatments, within experimental periods. 1 In addition, all diets used in Experiment 1 contained $4 \mathrm{~g} / \mathrm{kg}$ chromic oxide as digestibility marker. In Experiments 2 and 3, the enzyme was premixed with the grain before mixing it with the other dietary ingredients.

\section{Chemical analysis}

At the end of Experiment 1, ileal digesta were thawed, pooled within gilt and period for the same diet, and homogenized. A subsample of cach homogenate was freeze-dried, and ground in a Wiley mill through a 1 -mm mesh screen. Samples of diets and ileal digesta were analysed for dry matter and crude protein (AOAC, 1984). Amino acid analysis of diets (Table 2) and ileal digesta, except for cystine and tryptophan, were performed at the University of Missouri Experiment Station 
Crude protein and amino acid content of the experimental dicts, $\mathrm{g} / \mathrm{kg} \mathrm{DM}$

\begin{tabular}{lcccc}
\hline & \multicolumn{2}{c}{$\begin{array}{c}\text { Sorghum diets } \\
\text { Experiments } 1 \text { and } 2\end{array}$} & \multicolumn{2}{c}{$\begin{array}{c}\text { Wheat dicts } \\
\text { Experiment } 3\end{array}$} \\
\cline { 2 - 3 } \cline { 5 - 6 } & low protein & high protein & low protein & high protein \\
\hline Crude protein & 124.9 & 176.1 & 112.1 & 168.9 \\
& & & & \\
Amino acids & 5.0 & 9.6 & 4.9 & 9.5 \\
arginine & 2.9 & 4.5 & 2.0 & 3.6 \\
histidinc & 5.0 & 7.9 & 4.4 & 7.0 \\
isoleucine & 15.2 & 18.9 & 8.8 & 13.0 \\
leucine & 8.0 & 8.0 & 8.0 & 8.0 \\
lysine & 2.7 & 3.3 & 2.2 & 2.8 \\
methionine & 6.3 & 9.3 & 6.2 & 8.8 \\
phenylalanine & 4.8 & 6.5 & 5.3 & 6.0 \\
threonine & 6.3 & 9.0 & 5.6 & 8.2 \\
valine & & & & \\
\hline
\end{tabular}

Chemical Laboratories (Columbia, MO). Chromic oxide was analysed according to Hill and Anderson (1958).

Statistical analysis

The data from Experiment 1 were analysed as a two-period crossover experimental design, using analysis of variance as described by Cochran and Cox (1987). The data from Experiments 2 and 3 were analyzed according to a randomized complete block design. There was a $2 \times 2$ factorial arrangement in each of the three experiments (the factors were $\mathrm{CP}$ level and addition of protease). The effect of protein and protease level and their interactions were tested (Cochran and Cox, 1987).

\section{RESULTS AND DISCUSSION}

\section{Experiment 1}

As expected, AA intake of pigs fed the LP diets, except for lysine, was lower $(\mathrm{P}<0.01)$ than of pigs fed the HP diet. Pigs fed the HP diet consumed between 20 (leucine) and $48 \%$ (arginine) more of each AA than pigs fed the LP diet. These results can be explained by the differences in the AA content between the LP and HP diets, all pigs consumed the same amount of feed within each experimental period. 
The results of AID of AA are presented in Table 3. The AID of all essential $\mathrm{AA}$, except for leucine, phenylalanine and alanine, were higher $(\mathrm{P}<0.0 \mathrm{l})$ in pigs fed the HP compared with pigs fed the LP diet. The average AA digestibility value in pigs fed the HP diet (0.77) was 7.1 percentage units higher than those fed the LP diet $(0.72)$. The digestibility differences for the individual AA ranged from 3.5 (methionine) to 14 (threonine) percentage units. These results are in agreement with those reported by Fan et al. (1994) and Cervantes et al. (1997) who reported higher AA digestibility values in diets containing higher levels of $\mathrm{CP}$ in growing pigs. Overall, protease addition to diets containing high compared to low protein levels did not affect $(\mathrm{P}>0.10)$ the AA digestibility values in pigs. However, the AID of all essential AA, except for lysine, were higher $(\mathrm{P}<0.01)$ in pigs fed the LP diet supplemented with protease, compared with those fed the LP diet without protease. In contrast, addition of protease to the HP dict did not affect $(\mathrm{P}>0.10)$ the AID value of any AA. Protease addition to the LP diet increased the AID values of

TABLE 3

Apparent ileal digestibility of amino acids in growing pigs fed low- or high-protein, sorghum-soyabcan meal diets supplemented with a fungal protease, \% (Experiment 1 )

\begin{tabular}{|c|c|c|c|c|c|}
\hline \multirow{2}{*}{ Amino acids } & \multicolumn{2}{|c|}{ Low protein } & \multicolumn{3}{|c|}{ High protein } \\
\hline & - protease & + protease & - protease & + proteasc & SE \\
\hline \multicolumn{6}{|l|}{ Essential } \\
\hline $\operatorname{arginine}^{a}$ & 71 & 73 & 83 & 84 & 0.006 \\
\hline histidine ${ }^{a, b}$ & 68 & 73 & 77 & 78 & 0.006 \\
\hline isoleucine $e^{a, b}$ & 69 & 74 & 77 & 78 & 0.005 \\
\hline leucine ${ }^{b, c}$ & 74 & 82 & 76 & 78 & 0.008 \\
\hline lysine & 75 & 76 & 79 & 79 & 0.005 \\
\hline methionine $e^{\mathrm{a} . \mathrm{b}}$ & 72 & 77 & 78 & 78 & 0.004 \\
\hline phenylalanin $\mathrm{c}^{\mathrm{b}}$ & 74 & 80 & 79 & 80 & 0.007 \\
\hline threonine $e^{a, b}$ & 54 & 59 & 69 & 72 & 0.009 \\
\hline valine $^{\mathrm{a} . \mathrm{b}}$ & 66 & 70 & 71 & 73 & 0.005 \\
\hline \multicolumn{6}{|l|}{ Non essential } \\
\hline alanine ${ }^{b}$ & 69 & 74 & 71 & 70 & 0.007 \\
\hline aspartate $^{a}$ & 65 & 68 & 77 & 78 & 0.005 \\
\hline glutamate & 74 & 80 & 80 & 79 & 0.006 \\
\hline glycinea & 33 & 29 & 58 & 61 & 0.026 \\
\hline proline & 49 & 60 & 69 & 68 & 0.036 \\
\hline serine $e^{a, b}$ & 66 & 73 & 78 & 79 & 0.006 \\
\hline tyrosine $e^{a . b}$ & 67 & 75 & 77 & 77 & 0.009 \\
\hline
\end{tabular}

a protcin level effect $(\mathrm{P}<0.01)$

- low protein vs low protein with protease $(\mathrm{P}<0.05)$

c interaction protein level $x$ protease $(\mathrm{P}<0.05)$ 
AA; the increases ranged from 2.0 (arginine) to $6.8 \%$ (leucine). Despite these increases, the AID values of AA in the LP, protease-supplemented diet were lower than those in pigs fed the HP diet without protease. Regarding the non-essential AA, protease supplementation to the LP diet increased $(\mathrm{P}<0.01)$ only the AID values of alanine, glutamate, serine and tyrosine.

It is interesting to note that protease only increased the AA digestibilities of the LP diet. These results may suggest that pigs fed the LP diets secreted less pancreatic proteases into the intestinal lumen than pigs fed the HP diet. This in turn might result in a decrease in protein digestion and AA absorption. However, Pöhland et al. (1993) did not find any effect of neither the type of diet or the protein source on the total activities of trypsin, chymotrypsin, $\alpha$-amylase, and lipase in pancreatic juice of pigs. These authors measured the exocrine pancreatic secretions of pigs fed diets containing soyabean meal or canola meal or barley or wheat.

Fan et al. (1994) conducted an experiment with growing pigs fed maize starchsoyabean meal diets ( $35 \mathrm{~kg} \mathrm{BW})$ to investigate the effect of dietary CP level on AID values of AA. These authors found a quadratic response and concluded that the AID of AA reaches a plateau when the threshold levels of the AA in the diets are exceeded. They also indicated that the thresholds levels of AA, at which apparent $\mathrm{AA}$ digestibilities do not increase, are characteristic of a specific diet, but suggested that the dietary thresholds levels of amino acids in SBM could be a valuable reference. The dietary protein source used in this study was SBM; therefore, it is possible to make comparisons between results from this study and studies by Fan et al. (1994).

The contents of AA in the HP diet in this study, except for lysine and arginine, were higher than the threshold levels reported by Fan et al. (1994). In contrast, the contents of AA in the LP diet, except for leucine, were lower than the threshold levels, ranging from 0.03 to 0.65 percentage units for the essential AA. Thus, protease addition to the HP diets might have not improved the AA digestibilities because the threshold levels were exceeded. On the other hand, the protease in the LP diet might have improved the AID values of AA because the threshold levels were not exceeded. Caine et al. (1997) determined the effect of treating soyabean meal with a crystalline protease on the AID of AA in young pigs. These authors also did not find an effect of soyabean treatment with protease, and suggested that the AID values of AA were not improved because the dietary AA contents exceeded the thresholds levels reported by Fan et al. (1994).

The content of soyabean meal was lower and that of sorghum was higher in the LP as compared with the HP diets. Individually, the AA digestibility of soyabean meal is higher than that in sorghum (NRC, 1998). Protein digestion in the small intestine is initiated by trypsin, which has strong affinity for lysine and arginine (Gardner, 1989); soyabean meal contains approximately 14 and 9 times more lysine and arginine, respectively, than sorghum (NRC, 1998). Thus, some of the AID 
variation between LP and HP diets may be attributed to that difference. The fungal enzyme was expected to complement the activity of the own animal's enzymes and increase the AID of AA in the LP diets. The lack of response, however, suggests that the optimum activity of the fungal enzyme was not reached under the intestinal lumen conditions of the pigs.

On the other hand, it is been suggested that anti-nutritional factors such as tannins and phytates can interfere with the digestion of protein. Tannin content affects the digestibility of AA, but low tannin sorghums have ileal AA digestibility similar to that of maize (Cousins et al., 1981). The sorghum used in these experiment was of the yellow endosperm-type, with low tannin content, but generally contains considerable amounts of phytates (Cromwell, 1992). Phytates interact with endosperm proteins through the AA lateral chains, to form stable proteinphytate complexes (Reddy et al., 1982). Therefore, the addition of a phytase may release some of the protein complexed with the phytates rendering some AA available for the animal. There is no available information regarding the effect of adding a phytase to sorghum-based diets, on the AA digestibility in pigs.

The results for the ID of AA are presented in Table 4. The ID of AA is defined as the difference between the intake and the ileal flow of each amino acid. As expected, the dietary CP level directly affected the ID of the essential AA $(\mathrm{P}<0.01)$. On the average, the ID of AA in pigs fed the HP diet was approximately $74 \%$ higher, compared to the LP diet. These differences ranged from 21 (leucine) to $124 \%$ (arginine). The ID of lysine, threonine, methionine and isoleucine (first four limiting AA in sorghum-soyabean meal diets) were $33,102,28$, and $72 \%$ higher

TABLE 4

Small intestine disappearance of essential amino acids in growing pigs fed low- or high protein, sorghum-soyabean meal diets supplemented with a fungal protease, $\mathrm{g} / \mathrm{d}$

\begin{tabular}{|c|c|c|c|c|c|}
\hline \multirow{2}{*}{ Essential amino acids } & \multicolumn{2}{|c|}{ Low protein } & \multicolumn{3}{|c|}{ High protein } \\
\hline & - protease & + protease & - protease & + protease & $\mathrm{SE}$ \\
\hline Arginine ${ }^{4}$ & 5.66 & 5.85 & 12.82 & 12.95 & 0.075 \\
\hline Histidinea,c & 3.17 & 3.38 & 5.54 & 5.66 & 0.032 \\
\hline Isoleucine $e^{\mathrm{a} . \mathrm{c}}$ & 5.56 & 5.90 & 9.75 & 9.92 & 0.049 \\
\hline Leucine $e^{\mathrm{a} . \mathrm{c}}$ & 18.15 & 19.79 & 23.03 & 22.95 & 0.197 \\
\hline Lysine" & 7.23 & 7.27 & 9.60 & 9.68 & 0.062 \\
\hline Methionine ${ }^{a, c}$ & 3.10 & 3.32 & 4.13 & 4.10 & 0.031 \\
\hline Phenylalanine $\mathrm{e}^{\mathrm{a}, \mathrm{c}}$ & 7.48 & 8.07 & 11.79 & 11.88 & 0.073 \\
\hline Threonine $\mathrm{a}^{\mathrm{a}}$ & 3.49 & 3.78 & 7.23 & 7.45 & 0.068 \\
\hline Valine $e^{\mathrm{a}, \mathrm{s}}$ & 6.68 & 7.03 & 10.24 & 10.53 & 0.070 \\
\hline
\end{tabular}

protein level effect $(\mathrm{P}<0.01)$

b interaction protcin level $x$ protease $(\mathrm{P}<0.05)$

- low protein vs low protein with protease $(\mathrm{P}<0.05)$ 
$(\mathrm{P}<0.01)$, respectively, in pigs fed the HP compared to pigs fed the LP diet. This can be explained as the result of a higher intake of each AA, as well as the higher AID values of AA in pigs fed the HP diet. Likewise for AID of AA, the overall ID of $\mathrm{AA}$ was not affected $(\mathrm{P}>0.10)$ by protease addition in the sorghum-soyabean meal diets. However, protease addition to the $L P$ diet caused an increase $(P<0.05)$ in the ID of histidine, isoleucine, leucine, methionine, phenylalanine, and threonine. In contrast, protease addition to the HP diet did not affect $(P>0.10)$ the ID of the essential AA.

\section{Experiment 2}

The results from this experiment are presented in Table 5. The protein level affected all parameters measured. Daily gain, feed and lysine intake were higher $(\mathrm{P}<0.01)$ in pigs fed the HP compared to the LP diets. Also, feed/gain ratio was better $(\mathrm{P}<0.01)$ in pigs fed the HP diet. This response is very similar to that previ-

TABLE 5

Performance of growing pigs fed low- or high-protein, sorghum-soyabean meal diets supplemented with a fungal protease (Experiment 2)

\begin{tabular}{lcccccc}
\hline \multirow{2}{*}{ Item } & \multicolumn{2}{c}{ Low protein } & & \multicolumn{3}{c}{ High protein } \\
\cline { 2 - 3 } \cline { 6 - 7 } & - protease & + protease & & - protease & + protease & SE \\
\hline Daily weight gain, $\mathrm{kg} / \mathrm{d}^{\mathrm{a}, \mathrm{c}}$ & 0.618 & 0.594 & & 0.761 & 0.698 & 0.012 \\
Feed intake, $\mathrm{kg} / \mathrm{d}^{\mathrm{a}}$ & 1.80 & 1.75 & & 2.07 & 1.95 & 0.030 \\
Lysine intake, $\mathrm{g} / \mathrm{d}^{\mathrm{a}}$ & 12.6 & 12.2 & & 14.5 & 13.6 & 0.207 \\
Fced/gain & 2.82 & 2.96 & & 2.71 & 2.81 & 0.033 \\
\hline
\end{tabular}

a protein level effect $(\mathrm{P}<0.01)$

${ }^{b}$ protein level effect $(\mathrm{P}<0.01)$

c protease effect $(\mathrm{P}<0.10)$

ously reported in growing-finishing pigs fed low protein sorghum- (Hansen et al., 1993; Cervantes et al., 1997) or maize-based diets (Russell et al., 1983). However, protease addition did not improve the performance of the pigs; in fact, it tended to depress $(\mathrm{P}<0.10)$ both daily gain and feed/gain ratio. The low growth rate observed in pigs fed the LP diets was closely associated with their lysine intake. Daily intake of total lysine by pigs fed the LP diets $(12.5 \mathrm{~g})$ was approximately $20 \%$ below the lysine requirement specified by NRC (1988); the consumption lysine by pigs fed the HP diets ( $14.5 \mathrm{~g} / \mathrm{d}$ ) was close to the requirement. Although both the HP and LP diets were formulated to contain the same lysine level, the difference in lysine intake was duc to the difference in feed intake between pigs fed the HP and the LP diets. 
The results obtained from the digestibility trial (Experiment 1) suggested that protease addition to the LP diet would improve pig performance. Based on the digestibility values and both feed intake and AA composition of diets used in Experiment 2 , the intakes of apparent ileal digestible lysine (first limiting amino acid) in this experiment were calculated. The intake of apparent digestible lysine by pigs fed the LP diets was approximately $16 \%$ lower compared with pigs fed the HP diets. Thus, even though protease addition increased the AA digestibility values in the LP diet, the intake of apparent ilcal digestible lysine was still lower than the amount required for maximum weight gain of growing pigs (NRC, 1988). This response indicates that the AID of AA in LP, sorghum-soyabean meal diets is not sufficiently increased by the addition of the protease.

Protein synthesis requires that all AA are available to the cells at the same time. Rolls et al. (1972) indicated that free AA's are absorbed more rapidly in the small intestine than protein-bound AA. This may become a problem when pigs are fed only once daily (Batterham, 1978), but it could be overcome by increasing the feeding frequency. The pigs used in this experiment were fed ad libitum; thus, the impact of feeding free AA on its availability to the tissue, during protein synthesis is negligible.

\section{Experiment 3}

The results from this experiment are presented in Table 6. There was no effect of protein level or protease supplementation to a wheat-based diet on daily gain, feed intake, lysine intake, and feed/gain ratio. Likewise in Experiment 2, the daily weight gain was closely related to the intake of lysine; regardless of the dietary protein level, the lysine intake in Experiment 3 was very similar to the level required for growing pigs (NRC, 1988). These results show that crystalline lysine and threonine can replace all the soyabean meal in wheat-based diets, without affecting the performance of growing pigs. The lack of response of pigs to protease-supplemented diets suggests that the activity of this protease does

TABLE 6 Performance of growing pigs fed low- or high-protein, wheat-based diets supplemented with a funga! protease (Experiment 3)

\begin{tabular}{lcccccc}
\hline \multirow{2}{*}{ Item } & \multicolumn{2}{c}{ Low protein } & & \multicolumn{3}{c}{ High protein } \\
\cline { 2 - 3 } \cline { 6 - 7 } & - protease & + proteasc & & - protease & + protease & SE \\
\hline Daily weight gain, $\mathrm{kg} / \mathrm{d}^{\mathrm{d} . \mathrm{c}}$ & 0.716 & 0.737 & 0.769 & 0.741 & 0.021 \\
Feed intake, $\mathrm{kg} / \mathrm{d}^{\mathrm{a}}$ & 1.83 & 2.07 & 1.91 & 1.88 & 0.047 \\
Lysine intake, $\mathrm{g} / \mathrm{d}^{\mathrm{a}}$ & 14.6 & 16.6 & 15.3 & 15.0 & 0.388 \\
Fecd/gain & 2.57 & 2.83 & & 2.50 & 2.54 & 0.062 \\
\hline
\end{tabular}


not complement the secretion and activities of proteolytic enzymes secreted by the pig.

Pigs fed LP wheat-based diets had a better performance that those fed the sorghum-based diets. Several factors may explain this difference. First of all, although both wheat and sorghum contain phytates, wheat also contains the enzyme phytase (Cromwell, 1992) that can help the animal to partially release the protein from the phytate-protein complex. Second, the AID of AA in wheat is higher than that of sorghum (Taverner et al., 1981; Lin et al., 1987; Furuya et al., 1988). Third, wheat appears to have a better AA balance than sorghum (Bergner, 1994; NRC, 1998), thus, wheat-based diets have an AA composition closer to the ideal protein (Wang and Fuller, 1989) than sorghum-based diets.

\section{CONCLUSIONS}

The protease supplementation to HP diet did not affect the AID values of AA, but increased these values in the LP diet. Although protease supplementation to the LP diet increased the AID of CP and AA, this difference was not sufficient to match the digestible AA supply by the HP diet. Protease supplementation did not affect either performance of growing pigs fed the sorghum- or the wheat-based diets. The level of $\mathrm{CP}$ in sorghum-soyabean meal diets affects the AID of CP and $\mathrm{AA}$; AA in LP diets are less digestible than those in HP diets. Pigs fed the LP, sorghum-based diet performed poorer than pigs fed the high protein diet, but the dietary protein level did not affect the performance of pigs fed the wheat-based dicts.

\section{ACKNOWLEDGEMENTS}

This study was funded by the Research System of the Universidad Autonoma of Baja California. The authors would like to thank Fermentaciones Mexicanas for providing us with threonine.

\section{REFERENCES}

AOAC, 1984. Official Methods of Analysis. Association of Official Analytical Chemists. 14th Edition. Washington, DC

Batterham E.S., O'Neill G.H., 1978. Effect of frequency of feeding on the response by growing pigs to supplements of free Iysinc. Brit. J. Nutr. 39, 265-270

Bergner H., 1994. Estimating protein quality of foods and feeds. Arch. Anim. Nutr. 45, 293-332 
Caine W.R., Sauer W.C., Tamminga S., Verstegen M.W.A., Schulze H., 1997. Apparent ilcal digestibilities of amino acid in newly weaned pigs fed diets with protease-treated soybean meal. J. Anim. Sci. 75, 2962-2969

Cervantes R.M., Cromwell, G.L., Knabe D., 1997. Ileal amino acid digestibility of low protein diets supplemented with amino acids of growing pig (in Spanish). Agrociencia 31, 149-155

Cervantes M., González V.M., González M.J., Rodriguez S., Flores L., 2000. Intestinal cannulation of growing pigs for pancreatic enzymes and amino acid digestibility studies. Agrociencia 34, $135-139$

Cochran W.G., Cox G.M., 1962. Experimenta! Designs. 2nd Edition. John Wiley and Sons, Inc. New York, NY

Corring T., Saucier R., 1972. Secretion pancreatique sur porc fistule. Adaption a la teneur en proteines du régime. Ann. Biol. Anim. Bioch. Biophys. 12, 223-241

Cousins B.W., Tanksley T.D. Jr., Knabe D.A., Żebrowska T., 1981. Nutrient digestibitity and performance of pigs fed sorghums varying in tannin concentration. J. Anim. Sci. 53, 1524-1537

Cromwell G.L., 1992. The biological availability of phosphorous in feedstuffs for pigs. Pig News lnf. $13(2), 75 \mathrm{~N}-78 \mathrm{~N}$

Cromwell G.L., 1996. Synthetic amino acids may improve performance, reduce nitrogen excretion. Feedstuffs 68,49

Fan M.Z., Sauer W.C., Hardin R.T., Lien K.A., 1994. Determination of apparent ileal amino acid digestibility in pigs: Effect of dietary amino acid level. J. Anim. Sci. 72, 2851-2859

Furuya S., Kaji Y., Asano T., Murayama R., 1988. Ileal digestibilities of amino acids in wheat bran, rice bran, rapeseed meal, grain sorghum, meat and bone meal and feather meal for growing pigs. Jpn. J. Zoot. Sci. 59, 407-413

Gardner M.L.G., 1984. Intestinal assimilation of intact peptides and proteins from the diet - a neglected field? Camb. Phil. Soc. Biol. Rev. 59, 289-331

Hansen J.A., Knabe D.A., Burgoon K.G., 1993. Amino acid supplementation of low-protein sorghum-soybean meal diets for 20- to 50-kilogram swine. J. Anim. Sci. 71, 442-451

Hill F.N., Anderson D.L., 1958. Comparison of metabolizable energy and productive energy determination with growing pigs. J. Nutr. 64, 587-603

Lin F.D., Knabe D.A., Tanksley T.D. Jr., 1987. Apparent digestibility of amino acids, gross energy and starch in corn, sorghum, wheat, barley, oat groats and wheat middlings for growing pigs. J. Anim. Sci. 64, 1655-1663

NRC, 1988. Nutrient Requirements of Swinc. 9th Edition. National Academy Press. Washington, DC

NRC, 1998. Nutrient Requirements of Swine. 10th Edition. National Academy Press. Washington, $\mathrm{DC}$

Pöhland U., Souffrant W.B., Sauer W.C., Mosenthin R., de Lange C.F.M., 1993. Effect of feeding different diets on the exocrine pancreatic secretion of nitrogen, amino acids and enzymes in growing pigs. J. Sci. Food Agr. 62, 229-234

Reddy N.R., Sathé S.K., Salunkhe D.K., 1982. Phytates in legumes and cereals. Adv. Food Res. 28, $1-92$

Rolls B.A., Porter J.W.G., Westergarth D.R., 1972. The course of digestion of different food proteins in the rat. 3 . The absorption of proteins given alone and with supplements of their limiting amino acids. Brit. J. Nutr. 28, 283-293

Russell L.E., Cromwell G.L., Stahly T.S., 1983. Tryptophan, threonine, isoleucine and methionine supplementation of a $12 \%$ protein, lysine-supplemented, corn-soybean meal diet for growing pigs. J. Anim. Sci. 56, 1115-1123 
Taverner M.R., Hume 1.D., Farrel D.J., 1981. Availability to pigs of amino acids in cereal grains. 2. Apparent and true ileal digestibility. Brit. J. Nutr. 46, 159-171

Wang T.C., Fuller M.F., The optimum dietary amino acid patten for growing pigs. I. Experiments by amino acid deletion. Brit. J. Nutr. 62, 77-89

\section{STRESZCZENIE}

\section{Wplyw dodatku proteazy grzybowej do nisko i wysoko-biatkowych diet z sorgo lub pszenicą i śrutą sojową na strawność jelitową aminokwasów i wyniki produkeyjne świń}

W trzech doświadczeniach, przeprowadzonych na rosnących świniach, badano wpływ dodatku do diet nisko (LP) i wysoko-bialkowych (HP) proteazy grzybowej na strawność jelitową aminokwasów i wyniki produkcyjne. Do doświadczenia 1 użyto 8 świń, o średniej m.c. $25 \mathrm{~kg}$, z przetokami w początkowej części dwunastnicy i koncu jelita bjodrowego. Doświadczenia 2 i 3 wykonano na 28 świniach o początkowej m.c. 27,5 i $24,0 \mathrm{~kg}$, odpowiednio. Skarmiano następujące dawki T: T1. nisko-białkową (LP); T2. LP+0,5 g proteazy/kg paszy (LP-P); T3. wysoko-białkową (HP); T4. HP+0,5 g proteazy/kg paszy (HP-P). W doświadczeniach 1 i 2 diety zawierały sorgo, w 3 - pszenicę.

Pozorna strawność jelitowa (AID) AA z wyjątkiem leucyny, była wyższa ( $P<0,01)$ u świn otrzymujących diety HP. Dodatek proteazy do dawki LP zwiçkszył $(\mathrm{P}<0,01)$ AID AA, z wyjątkiem lizyny, natomiast dodatek proteazy do diety HP nie miał wpływu $(\mathrm{P}>0,01)$ na pozoną strawnośc $\mathrm{AA}$. Ubytek (ID) AA w jelitach był większy $(\mathrm{P}<0,01)$ u świń żywionych dietami HP niż LP. Dodatek proteazy do tej ostatnicj diety zwiçkszył $(\mathrm{P}<0,05)$ ID aminokwasów, lecz w mniejszym stopniu niż do dawki HP ( $P>0,05)$. Świnie żywione dietą $\mathrm{HP}$ z sorgo miały większe przyrosty, pobierały więcej paszy i lepiej ją wykorzystywały $(P<0,05)$ niż otrzymujące dietę LP; nie stwierdzono wpływu poziomu białka $(P>0,05)$ na te wskaźniki przy skarmianiu diet z pszenicą. Wystąpiła tendencja pogorszenia wyników produkcyjnych przy dodatku proteazy do diet z sorgo i brak wplywu enzynu przy podawaniu diet z pszenicą.

Otrzymane wyniki wskazuja, że ezynnikami ograniczającymi wzrost świń żywionych dietami LP uzupełnionymi AA, i zawierającymi sorgo i śrute sojową, są pobranie lizyny i treoniny. Wskazują one także na brak dodatnicgo wpływu dodatku proteazy do diet z sorgo i pszenicą na strawność jelitową AA i wyniki produkcyjne rosnących świn. 